\title{
PENGAJARAN BAHASA MELAYU DALAM KALANGAN PELAJAR ASING: ANALISIS POLA KESALAHAN TATABAHASA DALAM PENULISAN
}

\author{
Zeckqualine Melai*1 \\ Dayang Nurlisa Abang Zainal Abidin 2 \\ 1,2, Fakulti Bahasa dan Komunikasi, Universiti Malaysia Sarawak \\ ${ }^{1}$ mzeckqualine@unimas.my \\ 2azadnurlisa@unimas.my
}

Manuscript received 19 October 2019

Manuscript accepted 25 February 2020

*Corresponding author

https://doi.org/10.33736/ils.2351.2020

\begin{abstract}
ABSTRAK
Kajian ini menghuraikan kesalahan tatabahasa dalam kalangan pelajar antarabangsa di Universiti Malaysia Sarawak (UNIMAS). Objektif utama kajian ini ialah mengenal pasti jenis-jenis kesalahan tatabahasa dalam aspek penulisan. Data kajian diperolehi dari bahagian penulisan dalam kertas jawapan para pelajar untuk kursus Bahasa Melayu Komunikasi Lanjutan pada peperiksaan akhir. Pendekatan analisis kontrastif dan analisis kesalahan diaplikasikan dalam menganalisis penulisan pelajar asing yang terlibat dalam kajian ini. Terdapat 38 orang pelajar yang terlibat dan mereka berasal dari negara Bangladesh, Jepun, Morocco, Tajikistan, Afrika, China, Indonesia dan Brunei. Terdapat 215 kesalahan tatabahasa yang telah dikenal pasti dalam kajian ini. Kesalahan tersebut dikategorikan kepada 2 aspek, aspek pertama ialah morfologi yang merangkumi kesalahan ortografi $76 \%$, dan leksikal $1 \%$. Manakala yang kedua ialah aspek sintaksis yang merangkumi unsur kelewahan $15 \%$, hukum D-M $8 \%$. Peratusan menunjukkan kesalahan ortografi mencatatkan kekerapan yang paling tinggi. Kesalahan ortografi dibahagikan kepada 3 kategori berdasarkan proses yang berlaku iaitu penukaran huruf dengan huruf lain $(\wedge)$, penambahan huruf dalam perkataan $(\wedge \wedge)$ dan pengguguran huruf dalam perkataan $(\wedge \wedge \wedge)$. Kesalahan ini dipengaruhi oleh latar belakang negara dan bahasa ibunda yang berbeza. Kajian ini turut mencadangkan penekanan dan bimbingan yang berbeza perlu diberikan kepada para pelajar yang terdiri daripada pelbagai latar belakang.
\end{abstract}

Keywords: Analisis kesalahan; tatabahasa; pelajar asing; Bahasa Melayu

Pengajaran Bahasa Melayu dalam Kalangan Pelajar Asing: Analisis Pola Kesalahan Tatabahasa dalam Penulisan 


\title{
MALAY LANGUAGE LEARNING AMONG FOREIGN STUDENTS: GRAMMATICAL ERRORS ANALYSIS PATTERN IN WRITING
}

\begin{abstract}
This study describes grammatical errors made by international students at Universiti Malaysia Sarawak (UNIMAS) in their written essays. The data were obtained from 38 students' writing script for the Advanced Malay Language Communication course during the final examination. Contrastive analysis and error analysis approaches were applied in analysing the errors. The students were from Bangladesh, Japan, Morocco, Tajikistan, Africa, China, Indonesia and Brunei. A total of 215 grammatical errors were identified in their writing. These errors are categorised into two aspects. The first aspect is morphology which includes $76 \%$ orthographic error, and $1 \%$ lexical error. The second aspect is the syntactic aspect which comprises $15 \%$ luxury element and $8 \%$ of the D-M law. The percentage indicates that orthographic errors recorded the highest frequency. Orthographic errors are divided into three categories based on the processes involved in the conversion of letters to other letters $(\wedge)$, addition of letters in words (^^) and abstractions in words $(\wedge \wedge \wedge)$. These errors are influenced by different national backgrounds and languages. This study also suggests that different emphasis and guidance should be given to students of different backgrounds
\end{abstract}

Keywords: Error analysis; grammar; foreign students; Malay language

\section{Pendahuluan}

Selepas kemerdekaan Malaysia pada tahun 1957, Bahasa Melayu telah dimartabatkan sebagai bahasa kebangsaan dan bahasa rasmi dan termaktub di dalam perlembagaan Malaysia perkara 152 (Awang Sariyan, 1996, hlm. 85). Di samping itu, bahasa Melayu juga memainkan peranan sebagai bahasa ilmu yakni sebagai medium dalam menyampaikan ilmu pengetahuan pada peringkat sekolah rendah dan sekolah menengah. Manakala penubuhan UKM pada tahun 1970 mendukung aspirasi bahasa Melayu sebagai bahasa ilmu pada peringkat pengajian tinggi awam. Selaras dengan usaha memartabatkan dan memperkenalkan bahasa Melayu di peringkat antarabangsa, maka Unimas menawarkan kursus Bahasa Melayu Komunikasi 2 (MPU3142) dan Bahasa Melayu Komunikasi Lanjutan (MPU 3322). Kursus ini memberikan pendedahan awal kepada pelajar tentang sistem bunyi dan struktur ayat bahasa Melayu. Para pelajar turut didedahkan dengan kosa kata asas untuk membolehkan mereka berkomunikasi dalam situasi-situasi harian dengan lebih mudah. Kursus ini juga menekankan aspek komunikasi lisan agar para pelajar dapat berinteraksi dengan masyarakat tempatan dengan lebih berkesan. $\mathrm{Di}$ samping itu, aspek budaya berbahasa Melayu juga diperkenalkan dalam kursus ini. Secara umumnya, objektif kursus MPU3322 ialah membolehkan para pelajar untuk:

1) Menerangkan penggunaan bahasa dalam pelbagai konteks komunikasi seharian.

Pengajaran Bahasa Melayu dalam Kalangan Pelajar Asing: Analisis Pola Kesalahan Tatabahasa dalam Penulisan 
2) Menghubungkaitkan penggunaan bahasa dalam adab dan budaya masyarakat di Malaysia.

3) Membentang laporan ringkas berkaitan dengan aspek budaya dan situasi sosial di Malaysia.

Kelaziman kesalahan tatabahasa tidak hanya berlaku dalam kalangan penutur natif bahasa Melayu bahkan juga dalam kalangan bukan penutur natif. Berdasarkan beberapa kajian sebelum ini terdapat beberapa titik kesukaran yang mengganggu prestasi para pelajar dalam menguasai bahasa Melayu sebagai bahasa kedua. Misalnya, kajian yang dilakukan oleh Yong dan Subramaniam (2012) mendapati tatabahasa merupakan aspek paling sukar untuk dikuasai oleh para pelajar. Keadaan ini secara tidak langsung menggambarkan kepelbagaian kesalahan tatabahasa merupakan petunjuk bahawa setiap pelajar yang berasal dari latar belakang yang berbeza juga memerlukan penekanan dan bimbingan yang berbeza. Namun demikian, kajian-kajian tersebut memerlukan kajian lanjutan dalam pelbagai sudut bagi memberi maklumat yang lebih banyak terhadap daerah kesulitan yang dialami oleh para pelajar. Penemuan titik kesukaran tersebut membantu para pengajar untuk meramal kesilapan yang dilakukan oleh para pelajar. Berdasarkan ramalan tersebut, mereka dapat merancang strategi pengajaran dan pembelajaran yang lebih efektif di dalam kelas. Oleh yang demikian, kajian ini dilakukan bukan sekadar menganalisis kesalahan bahasa tetapi turut mengenal pasti faktor-faktor yang mempengaruhi para pelajar untuk melakukan kesalahan tersebut. Dalam kajian ini juga turut dicadangkan beberapa strategi pengajaran dan pengajaran yang mungkin dapat membantu para pengajar dalam merancang proses pengajaran dan pembelajaran yang lebih berkesan.

Kajian ini meneliti kesalahan tatabahasa dalam bahasa Melayu dalam kalangan pelajar antarabangsa di UNIMAS. Objektif khusus kajian ialah:

1) Untuk mengenal pasti kesalahan tatabahasa pelajar asing dalam penguasaan leksikal dan ayat asas bahasa Melayu.

2) Untuk mengklasifikasikan pola/jenis kesalahan tatabahasa yang dilakukan oleh pelajar asing dalam mempelajari bahasa Melayu.

Berdasarkan kajian ini, pengenalpastian kekerapan terhadap aspek kesalahan tatabahasa dalam pembelajaran bahasa Melayu dapat membantu tenaga pengajar meramal kesilapan atau daerah kesukaran yang dihadapi oleh para pelajar. Hasil analisis terhadap kesalahan tersebut dapat digunakan sebagai asas dalam merancang strategi dalam sesi pengajaran dan pembelajaran lebih efektif. Di samping itu, kajian ini penting khususnya kepada bakal tenaga pengajar yang akan bertanggung jawab mendidik para pelajar dalam bidang pengajaran bahasa Melayu sebagai bahasa asing atau bahasa kedua. Selain itu, hasil kajian ini juga dapat dijadikan sumber rujukan dan maklumat kepada para pengajar untuk mempertingkatkan keberkesanan pengajaran dan pembelajaran. Seterusnya, penguasaan bahasa Melayu yang baik dalam kalangan pelajar tersebut dapat memperkenalkan bahasa Melayu ke peringkat antarabangsa.

Pelajar "asing" merujuk kepada pelajar bukan warganegara Malaysia. Dalam Kamus Dewan (Dewan Bahasa dan Pustaka, 2007), istilah "asing" ditakrifkan sebagai

Pengajaran Bahasa Melayu dalam Kalangan Pelajar Asing: Analisis Pola Kesalahan Tatabahasa dalam Penulisan 
berasal dari daerah atau negara lain. Oleh yang demikian dalam konteks kajian ini "pelajar asing" merujuk kepada para pelajar yang berasal dari negara-negara luar seperti Bangladesh, Jepun, Morocco, Tajikistan China, Afrika, Indonesia dan Brunei Darussalam (Rujuk Jadual 1).

Jadual 1

Jumlah pelajar antarabangsa yang mengikuti Kursus MPU3322

\begin{tabular}{lc}
\hline Bil.Negara & Jumlah \\
\hline 1 Bangladesh & 24 \\
2 Jepun & 4 \\
3 Morocco & 1 \\
4 Tajikistan & 1 \\
5 Afrika & 1 \\
6 China & 1 \\
7 Indonesia & 3 \\
8 Brunei Darussalam & 3 \\
\hline Jumlah & $\mathbf{3 8}$ \\
\hline
\end{tabular}

\section{Sorotan Kajian}

Berdasarkan sorotan kajian lepas, terdapat pelbagai kesalahan tatabahasa yang digunakan oleh para pelajar yang mempelajari bahasa asing atau bahasa kedua. Kesalahan tersebut bukan sahaja dalam aspek tulisan tetapi juga secara lisan. Antara kesalahan tatabahasa yang paling banyak dilakukan dalam mempelajari bahasa kedua ialah kesalahan ortografi. Kesalahan ini berlaku akibat pengaruh daripada sebutan atau bunyi-bunyi dalam bahasa ibunda. Misalnya, dalam konteks di Malaysia, pelajar Cina mengalami kesukaran mempelajari bahasa Melayu apabila ejaan huruf " $r$ " ditukar dengan huruf "l", contohnya lari menjadi lali (Medan Sandra Kasih, 2003). Manakala bagi kaum pelajar India pula, didapati kerap berlaku proses penggantian fonem vokal bahasa Melayu dalam penulisan karangan. Misalnya berlaku penggantian fonem /e/ kepada /a/, /a/ kepada /o/, /e/ kepada /i/, /u/ kepada /o/ dan /i/ kepada /e/. Selain itu, masyarakat Kensiu (Orang Asli) juga mengalami kesukaran mempelajari bahasa Melayu kerana faktor bahasa ibunda. Para pelajar ini sukar memahami sebutan bahasa Melayu dan masih ramai yang tidak kenal huruf. Keadaan ini mengakibatkan mereka mengalami kesukaran dalam mengeja dan penguasaan leksikal bahasa Melayu. Dalam konteks pelajar asing pula, kesilapan ortografi/ ejaan dapat digolongkan kepada lima aspek mengikut tahap kesukaran penguasaan yakni kata angka asas, diikuti kata tanya, kata komunikasi asas, kata ganti nama diri, dan akhirnya kata sapaan (Yong \&Vijayaletchumy, 2012). Seterusnya Ting, Mahanita, dan Chang (2010) pula mendapati terdapat lima jenis kelaziman tatabahasa yang dilakukan oleh pelajar dalam menuturkan bahasa Inggeris sebagai bahasa kedua. Antara kesalahan tersebut ialah preposisi, kata tanya, artikel, unsur jamak kata nama (plural form of noun) dan unsur kata kerja (subject-verb agreement and tense).

Pengajaran Bahasa Melayu dalam Kalangan Pelajar Asing: Analisis Pola Kesalahan Tatabahasa dalam Penulisan 


\section{Metodologi}

Kajian ini berfokus pada kesalahan tatabahasa dalam bahagian penulisan peperiksaan akhir semester (Sem 2 2017-2018) bagi kursus Bahasa Melayu Komunikasi Lanjutan (MPU 3322). Sebelum mengambil kursus ini, para pelajar perlu lulus dalam kursus Bahasa Melayu Komunikasi 2 (MPU3142). Kursus MPU 3322 mempunyai tahap yang lebih tinggi jika dibandingkan dengan kursus MPU 3142. Kesalahan tatabahasa yang dianalisis dalam kajian ini merangkumi aspek morfologi (ortografi dan leksikal) dan sintaksis (hokum D-M dan kelewahan). Terdapat 38 orang pelajar yang terlibat dalam kursus ini dan mereka berasal dari pelbagai negara seperti yang ditunjukkan dalam Jadual 1.

Secara umumnya, kajian ini menggunakan pendekatan kualitatif dalam menganalisis data kajian. Dalam kajian kualitatif data-data yang dikumpul digunakan untuk memperhalusi model kajian lalu membentuk kategori-kategori khusus yang mantap (Rasid Mail \& Raman Noordin, 2015). Oleh yang demikian dalam kajian ini, data-data kesalahan tatabahasa akan diklasifikasikan mengikut kategori tertentu seperti kesalahan ortografi, leksikal dan ayat. Walau bagaimanapun, kaedah kuantatif digunakan secara tidak langsung dalam kajian ini, khususnya dalam menggambarkan kekerapan penggunaan kesalahan tatabahasa dengan menggunakan perisian SPSS. Misalnya, kekerapan akan ditunjukkan dalam statistik dan graf-graf tertentu untuk memudahkan huraian dalam analisis data.

\section{Sampel Kajian}

Pemilihan sampel bagi kajian ini melibatkan 38 orang pelajar antarabangsa pada peringkat pra siswazah yang mengambil kursus MPU 3322 di Fakulti Bahasa dan Komunikasi. Para pelajar ini mengikuti kursus MPU 3322 dalam kelas yang sama dan diajar oleh guru bahasa yang sama. Sukatan pelajaran yang digunakan dalam kursus ini berdasarkan kerangka yang disediakan dalam Mata Pelajaran Umum (MPU) daripada Kementerian Pengajian Tinggi (KPT, 2016). Dalam kebanyakan sampel yang terlibat, bahasa Melayu (BM) merupakan bahasa asing mereka selepas bahasa ibunda dan bahasa Inggeris (BI). Walaupun pelajar dari Brunei dan Indonesia menuturkan BM, namun terdapat perbezaan BM di Malaysia dengan BM yang mereka tuturkan di negara asal khususnya dalam aspek tatabahasa dan istilah-istilah tertentu. Proses pengajaran dan pembelajaran di dalam kelas ini menggunakan kaedah dwi bahasa iaitu BM dan BI sebagai medium penyampaian kuliah.

\section{Instrumen Kajian}

Dalam penyelidikan ini, data kesalahan bahasa diperolehi daripada kertas jawapan pelajar dalam peperiksaan akhir semester kursus MPU 3322. Kertas soalan peperiksaan tersebut terbahagi kepada dua bahagian. Bahagian A merupakan soalan berbentuk objektif yang menguji pemahaman para pelajar berdasarkan teks. Manakala bahagian B terdiri daripada soalan berbentuk subjektif (isi tempat kosong) dan soalan penulisan. Jika dilihat daripada bentuk-bentuk soalan tersebut, didapati soalan pada bahagian penulisan merupakan sumber untuk mendapatkan data

Pengajaran Bahasa Melayu dalam Kalangan Pelajar Asing: Analisis Pola Kesalahan Tatabahasa dalam Penulisan 
kesalahan penggunaan tatabahasa dalam kalangan pelajar. Hal ini demikian kerana, dalam penulisan, para pelajar diminta untuk mengolah dan menghuraikan ayat sendiri bagi menghasilkan sebuah esei mudah dalam 100 patah perkataan. Soalan tersebut berkaitan tentang pengalaman perjalanan mereka dari negara asal hingga tiba di kampus UNIMAS. Selain itu, terdapat beberapa frasa yang disediakan untuk memudahkan para pelajar mengembangkan idea. Antara perkataan frasa yang disediakan ialah "negara saya", "menaiki kapal terbang", "sedih kerana terpaksa berpisah", "tiba di lapangan terbang Malaysia", "menaiki teksi" dan "kampus universiti". Berdasarkan frasa "negara saya" dapat dilihat latar belakang pelajar untuk dijadikan data demografi dalam kajian ini.

\section{Prosedur Analisis Konstraktif dan Analisis Kesalahan}

Terdapat dua pendekatan yang diaplikasikan untuk menganalisis data dalam kajian. Pendekatan yang pertama ialah analisis kontrastif. Dalam pengajaran bahasa analisis kontrastif lazimnya digunakan sebagai pendekatan yang digunakan untuk membandingkan struktur dua bahasa atau lebih secara sistematik (Fries, 1945). Perbandingan tersebut bertujuan untuk melihat wujudnya perbezaan atau persamaan antara bahasa-bahasa yang dibanding. Berdasarkan asas pendekatan analisis kontrastif, pelajar bahasa asing mudah mempelajari aspek-aspek bahasa sasaran yang sama dengan bahasa natif mereka. Namun aspek-aspek yang berlainan antara bahasa sasaran dan bahasa natif akan menjadi titik kesulitan dalam proses pembelajaran bahasa sasaran. Pendekatan kedua pula ialah analisis kesalahan. Kesalahan/ kesilapan merupakan aspek yang sebagai signifikan iaitu sesuatu yang mempunyai maksud tersendiri untuk pelajar dan pengajar atau pengkaji bahasa (Corder, 1974). Kesalahan ini berlaku dalam komunikasi lisan dan tulisan disebabkan faktor-faktor seperti kurang tumpuan, keletihan, kecuaian dan sebagainya.

Di samping itu, aspek-aspek kesalahan yang dilakukan oleh pelajar asing semasa mempelajari bahasa sasaran atau bahasa kedua dapat menggambarkan titik kesulitan yang mereka hadapi. Titik kesulitan yang dikesan inilah yang boleh dijadikan merupakan fokus guru bahasa asing terhadap pelajar mereka. Berdasarkan pendekatan analisis kesalahan, pengaruh bahasa natif bukannya faktor tunggal yang mewujudkan kesalahan, malah terdapat sebab-sebab lain yang turut menyumbang kepada kesalahan tersebut. Antaranya faktor lain yang dimaksudkan ialah intralingual yang disebabkan oleh bahasa sasarannya sendiri dan bersifat "developmental". Kesalahan ini merangkumi bentuk atau jenis perkataan. Selain itu, keberkesanan pembelajaran bahasa sasaran juga disebabkan oleh strategi belajar, teknik mengajar, pengetahuan kebudayaan terhadap bahasa kedua dan sosiolinguistik (Jian, 1974). Tuntasnya, kedua-dua pendekatan ini yakni analisis kontrastif dan analisis kesilapan saling berkaitan. Analisis kontrastif berfungsi untuk mengesan perbezaan dan persamaan antara bahasa sasaran dan bahasa ibunda. Berdasarkan perbandingan tersebut dapatlah dirumuskan aspek-aspek gangguan bahasa ibunda terhadap bahasa sasaran. Kemudian rumusan ini dapat diaplikasikan untuk meramal kesulitan serta menerangkan kesalahan yang dilakukan para pelajar ini dalam proses pembelajaran bahasa sasaran.

Pengajaran Bahasa Melayu dalam Kalangan Pelajar Asing: Analisis Pola Kesalahan Tatabahasa dalam Penulisan 


\section{Dapatan Kajian dan Perbincangan}

Bahagian ini akan membincangkan hasil dapatan kajian analisis kesalahan tatabahasa. Menurut Nik Safiah Karim, Farid M. Onn, Hashim Haji Musa, dan Abdul Hamid Mahmood (2015), bahasa merangkumi jumlah ayat yang tidak terbilang, manakala ayat pula terhasil daripada beberapa perkataan yang bermakna. Kajian terhadap tatabahasa lazimnya dilakukan dalam dua aspek. Aspek yang pertama ialah dari segi cara perkataan terhasil daripada bunyi bahasa, manakala aspek yang kedua ialah dari susunan perkataan itu untuk menjadi ayat. Huraian penghasilan pada peringkat "perkataan" melibatkan bidang morfologi manakala huraian pada peringkat ayat melibatakan bidang sintaksis. Oleh yang demikian kesalahan tatabahasa dalam kajian ini akan dihurai berdasarkan beberapa kategori iaitu morfologi (yang merangkumi kesalahan ortografi dan leksikal) dan sintaksis (merangkumi kesalahan hukum D-M dan kelewahan). Sila rujuk Lampiran 1 untuk senarai kesalahan.

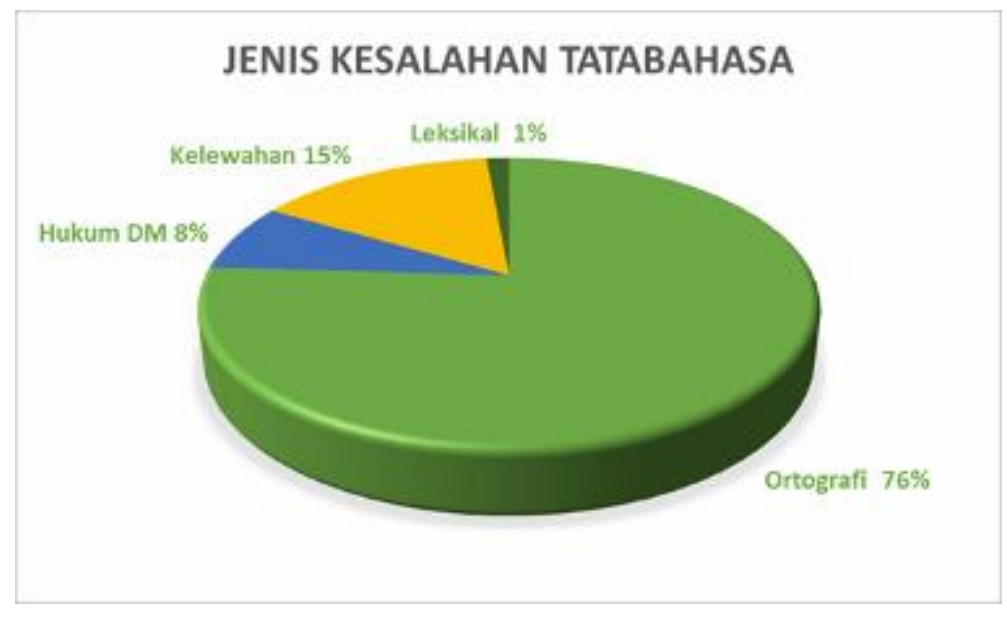

Rajah 1. Jenis kesalahan tatabahasa

\section{Morfologi}

Menurut Mathews (1991, hlm. 1) morfologi "merupakan cabang linguistik yang mengkaji bentuk-bentuk perkataan". Dalam kajian ini mendapati wujud beberapa jenis kesalahan tatabahasa dalam aspek morfologi iaitu kesalahan ortografi dan leksikal.

\section{Ortografi/ejaan.}

Hasil kajian mendapati bahawa kesalahan ortografi adalah kesalahan yang paling banyak dilakukan oleh para pelajar iaitu sebanyak $76 \%$. Kesalahan ini dapat dikategorikan berdasarkan proses perubahan perkataan dan ditandakan dengan simbol seperti yang ditunjukkan dalam Jadual 2 . 
Jadual 2

Jenis kesalahan ortografi

\begin{tabular}{ll}
\hline Jenis kesalahan ortografi & Simbol \\
\hline a. Penukaran huruf dengan huruf lain & $\left({ }^{\wedge}\right)$ \\
b. Penambahan huruf dalam perkataan & $\left({ }^{\wedge \wedge}\right)$ \\
c. Pengguguran huruf dalam perkataan & $\left({ }^{\wedge \wedge \wedge}\right)$ \\
\hline
\end{tabular}

a. Penukaran huruf dengan huruf lain $(\wedge)$

Dari aspek pertukaran huruf dengan huruf lain, wujud perbandingan yang ketara di antara pelajar Bangladesh dan Jepun. Jadual 3 menunjukkan contoh penukaran huruf dengan huruf yang lain dalam kalangan tersebut. Berdasarkan contoh dalam Jadual 3, ternyata bahasa natif penutur turut mempengaruhi bunyi sebutan dalam bahasa Melayu. Misalnya, pelajar Bangladesh kerap menukar vokal depan " $\mathrm{e}$ " kepada perkataan yang mempunyai vokal belakang "a" dan sebaliknya. Manakala pelajar Jepun kerap menggunakan vokal belakang tinggi " $u$ " untuk menggantikan vokal depan separuh tinggi " $\mathrm{e}$ ".

Jadual 3

Contoh kesalahan $(\wedge)$

\begin{tabular}{cccc}
\hline \multicolumn{2}{c}{ Bangladesh } & \multicolumn{2}{c}{ Jepun } \\
\hline Kesalahan & Gembira & gumbira & gembira \\
gambira & kapal terbang & gumbila & gembira \\
kepal terbang & berbagai & lateh & letih \\
berbegai & Selepas itu & mureka & mereka \\
Salapas itu & Sulan
\end{tabular}

b. Penambahan huruf dalam perkataan $(\wedge \wedge)$

Kesalahan penambahan huruf berlaku dengan menambah huruf vokal pada suku kata tertutup. Dalam jadual 4 didapati para pelajar menambah huruf vokal "a" pada suku kata tertutup konsonan vokal (VK) dan menjadikan struktur asal yang mempunyai 4 suku kata /di/la/hir/kan menjadi lima suku kata iaitu/di/la/hi/ra/kan/.

Jadual 4

Contoh kesalahan (^^)

\begin{tabular}{cc}
\hline Kesalahan & Pembetulan \\
\hline dilahirakan & Dilahirkan \\
pengaijian & Pengajian \\
memindahakan & memindahkan \\
\hline
\end{tabular}

Pengajaran Bahasa Melayu dalam Kalangan Pelajar Asing: Analisis Pola Kesalahan Tatabahasa dalam Penulisan 
c. Pengguguran huruf dalam perkataan (^^^)

Dalam Jadual 5 terdapat pengguguran konsonan dan vokal pada perkataan. Misalnya vokal "e" digugurkan dalam perkataan "pelajar" dan "beberapa". Keadaan tersebut menjadi suku kata disingkatkan daripada perkataan asal. Misalnya /pe/la/jar/ yang terdiri daripada tiga suku kata telah disingkatkan menjadi dua suku kata iaitu /pla/jar/.

Jadual 5

Contoh kesalahan (^^^)

\begin{tabular}{cc}
\hline Kesalahan & Pembetulan \\
\hline plajar & Pelajar \\
sepati & Seperti \\
banya & Banyak \\
bebrapa & beberapa \\
\hline
\end{tabular}

\section{Leksikal.}

Kesalahan leksikal merujuk kepada pengaruh bahasa ibunda dalam penggunaan bahasa Melayu sebagai bahasa kedua. Berikut ialah contoh pengaruh bahasa ibunda yang didapati dalam karangan BM.

Jadual 6

Pengaruh Leksikal Bahasa Ibunda

\begin{tabular}{ll}
\hline \multicolumn{1}{c}{ Kesalahan } & \multicolumn{1}{c}{ Pembetulan } \\
\hline Saya memiliki harapan selepas selesai & Saya berharap selepas tamat belajar \\
masa perkuliahan, saya bekerja di & untuk bekerja di syarikat besar dan \\
syarikat besar dan menolong orang lain menolong mereka yang memerlukan. \\
yang membutuhkan.
\end{tabular}

Berdasarkan ayat dalam Jadual 6, terdapat beberapa leksikal yang dipengaruhi oleh bahasa ibunda. Ayat tersebut merupakan ayat pelajar dari Indonesia. Walaupun BM dan bahasa Indonesia tergolong dalam bahasa serumpun, namun terdapat beberapa leksikal yang membawa maksud yang berbeza mengikut konteks di Malaysia. Misalnya, "selesai" memang sinonim dengan perkataan "tamat" yang membawa maksud "sudah". Namun dalam konteks BM di Malaysia 'selesai' tidak digunakan merujuk waktu kuliah atau sekolah seperti dalam ayat tersebut. Lazimnya, BM dalam konteks di Malaysia menggunakan perkataan "tamat". Contoh yang seterusnya ialah "membutuhkan" digunakan dalam BM yang juga pengaruh daripada bahasa Indonesia, sedangkan perkataan yang tepat dalam BM untuk merujuk situasi dalam ayat tersebut ialah "memerlukan". Keadaan ini berlaku kerana para pelajar terpengaruh dengan penggunaan istilah tersebut dalam bahasa asal mereka, sedangkan dalam konteks BM di Malaysia ia dirujuk dengan istilah yang berbeza.

Pengajaran Bahasa Melayu dalam Kalangan Pelajar Asing: Analisis Pola Kesalahan Tatabahasa dalam Penulisan 


\section{Sintaksis.}

Kesalahan sintaksis dikategorikan kepada dua aspek iaitu kesalahan hukum D-M dan kelewahan dalam ayat.

\section{a. Hukum D-M}

Hukum D-M bermaksud Diterang-Menerangkan. la merupakan peraturan susunan frasa dalam bahasa Melayu. Dalam susunan frasa bahasa Melayu, kata yang diterangkan (D) MESTI hadir dahulu, diikuti oleh kata yang menerangkan (M). Misalnya, "rumah besar", terbentuk daripada kata "rumah" yang diterangkan dan diikuti kata "besar" yang menerangkan tentang keadaan rumah tersebut. Hal yang sebaliknya berlaku dalam susunan frasa bahasa Inggeris iaitu kata yang menerangkan hadir di hadapan kata yang diterangkan, misalnya "Adam's Restaurant". Hasil daripada kajian ini mendapati para pelajar turut dipengaruhi oleh susanan frasa dalam bahasa Inggeris. Berikut merupakan contoh kesalahan hukum D-M yang telah dianalisis (Jadual 7):

Jadual 7

Contoh kesalahan hukum D-M

\begin{tabular}{ll}
\hline Kesalahan & Pembetulan \\
\hline Malaysia Syarikat & Syarikat Malaysia \\
hati baik & baik hati \\
seronok kehidupan & kehidupan seronok \\
saya fakulty & Fakulti saya \\
bahasa Melayu peperiksaan & Peperiksaan bahasa Melayu \\
\hline
\end{tabular}

Berdasarkan Jadual 7 terdapat beberapa kesalahan tatabahasa yang tidak mematuhi hukum D-M dalam bahasa Melayu. Misalnya, frasa "Malaysia syarikat" sepatutnya disusun sebagai "syarikat Malaysia" kerana unsur yang diterangkan (D) iaitu syarikat mesti mendahului unsur yang menerangkan (M). Hal ini demikian kerana, syarikat itu ialah milik Malaysia.

b. Sintaksis (Kelewahan)

Amalan kelewahan bermaksud penggunaan kata, frasa ataupun ungkapan secara berlebihan dalam penulisan dan jika digunakan tidak pula menambah maksud, malah merosakkan kelancaran dan kepersisan sesuatu ayat. Misalnya dalam ayat "Para peserta hanya diminta membayar RM 2 sahaja" menunjukkan berlaku kelewahan penggunaan perkataan iaitu "hanya" dan "sahaja". Hal ini demikian kerana "hanya" dan "sahaja" mempunyai kepersisan atau maksud yang sama. Oleh itu, dalam ayat tersebut sepatutnya menggunakan salah satu perkataan sama ada "hanya" atau "sahaja". Contonya seperti ayat berikut:

1) Para peserta hanya diminta membayar RM 2.

2) Para peserta diminta membayar RM 2 sahaja.

Pengajaran Bahasa Melayu dalam Kalangan Pelajar Asing: Analisis Pola Kesalahan Tatabahasa dalam Penulisan 
Terdapat beberapa kesalahan yang telah dikesan dalam kajian ini (Jadual 8). Berdasarkan contoh dalam Jadual 8, didapati kesalahan kelewahan seperti pengulangan kata penguat dan pengulangan perkataan berbeza tetapi mempunyai kepersisan maksud. Misalnya dalam ayat 1 , penggunaan kata penguat 'sangat' dan "ter" membawa maksud yang sama iaitu "amat". Begitu juga dalam ayat 2, penggunaan kata adjektif "baik" merujuk maksud yang sama dengan kata "elok". Oleh itu, untuk mengelakkan berlakunya kelewahan dalam ayat tersebut, maka perlulah dipilih salah satu perkataan sahaja seperti yang telah dinyatakan dalam bahagian pembetulan ayat.

Jadual 8

Contoh kesalahan kelewahan

\begin{tabular}{|c|c|}
\hline Kesalahan & Pembetulan \\
\hline $\begin{array}{l}\text { la merupakan sesuatu yang sangat } \\
\text { terindah bagi saya. }\end{array}$ & $\begin{array}{l}\text { la merupakan sesuatu yang sangat indah } \\
\text { bagi saya. }\end{array}$ \\
\hline $\begin{array}{l}\text { Mereka berhati baik dan elok. } \\
\text { la adalah perjalanan pertema saya } \\
\text { menaiki kapal terbang, saya berasa } \\
\text { seronok perjalanan pertema saya. } \\
\text { Saya sangat sangat suka Sarawak. }\end{array}$ & $\begin{array}{l}\text { Mereka sangat baik hati. } \\
\text { la adalah perjalanan pertema saya } \\
\text { menaiki kapal terbang, saya berasa } \\
\text { seronok perjalanan pertema saya. } \\
\text { Saya sangat suka Sarawak. }\end{array}$ \\
\hline
\end{tabular}

Secara umumnya, kesalahan ortografi merupakan kesalahan yang paling kerap dilakukan oleh para pelajar asing dari negara seperti Bangladesh, Jepun, Morocco, Tajikistan China, Afrika, Indonesia dan Brunei Darussalam. Hasil kajian ini menyerupai dapatan kajian yang dilakukan oleh Yong dan Subramaniam (2012), yakni kekerapan kewujudan kesalahan ortografi dalam kalangan para pelajar antarabangsa. Namun demikian hasil kajian ini berbeza dengan dapatan kajian dalam pembelajaran bahasa Inggeris sebagai bahasa kedua di Malaysia. Misalnya, dalam kajian Ting, Mahadhir, dan Chang (2010) mendapati dalam pembelajaran bahasa Inggeris, kekerapan kesilapan yang paling banyak dilakukan ialah dalam aspek kata sendi nama dan diikuti kata tanya. Berdasarkan kajian ini dapatlah diramal bahawa aspek yang perlu ditekankan dalam pembelajaran bahasa Melayu bagi para pelajar antarabangsa ialah aspek ortografi.

Oleh yang demikian para pelajar ini memerlukan latih tubi yang menekan aspek tersebut semasa di dalam kelas. Misalnya, latihan mendengar dan mengeja perkataan-perkataan yang disebut sama ada melalui video, audio atau para pengajar sendiri. Kesalahan ini dapat dimininumkan sekiranya pembetulan dilakukan semasa sesi pembelajaran. Para pelajar juga dapat didedahkan dengan sebutan yang tepat agar tidak terpengaruh dengan bunyi-bunyi vokal dan konsonan daripada bahasa ibunda mereka. Misalnya, kekerapan penukaran vokal "a" kepada vokal "e" seperti yang dilakukan oleh pelajar Bangladesh dapat diminimumkan sekiranya mereka kerap menjalankan latih tubi pendengaran dan sebutan. Selain itu, bagi pelajar Indonesia khususnya perlu ditekankan bahawa terdapat istilah-istilah yang sama dalam bahasa Indonesia tetapi mempunyai makna dan fungsi daripada BM. Para

Pengajaran Bahasa Melayu dalam Kalangan Pelajar Asing: Analisis Pola Kesalahan Tatabahasa dalam Penulisan 
pelajar ini harus menggunakan istilah sesuai berdasarkan konteks BM dan di Malaysia.

\section{Kesimpulan}

Secara kesimpulannya kajian ini dapat dijadikan asas rujukan dalam kalangan para pengajar kursus ini pada masa-masa yang akan datang. Hal ini demikian kerana hasil kajian membincangkan beberapa kelaziman dan kekerapan kesalahan tatabahasa yang dilakukan oleh para pelajar. Penemuan aspek-aspek kesalahan seperti ortografi, leksikal, hukum D-M dan kelewahan para pengajar dapat lebih peka dan membantu mereka membuat persediaan apabila berhadapan dengan para pelajar yang datang dari latar belakang yang sama. Bagi meningkatkan penglibatan para pelajar dalam sesi pembelajaran mereka harus diberi peluang yang lebih kerap untuk bertanya dan mempraktikkan penggunaan bahasa Melayu. Dalam meningkatkan motivasi para pelajar dalam mempelajari bahasa Melayu, para pengajar boleh menggunakan pemberian ganjaran berbentuk pujian. Selain itu, teknik pengajaran yang pelbagai seperti berbantukan teknologi seperti video, audio, kuiz dan permainan atas talian dan bukan talian dapat meningkatkan minat para pelajar untuk mengikuti sesi pembelajaran di dalam kelas. Secara tidak langsung keadaan ini akan meningkatkan dan menyebarkan penggunaan bahasa Melayu di peringkat antarabangsa.

\section{Rujukan}

Awang Sariyan (1996). Warna dan suasana. Perancangan Bahasa Melayu di Malaysia. Kuala Lumpur: Dewan Bahasa dan Pustaka.

Corder, S. P. (1974). The significance of learners' errors. DIm. J. C Richards (pnyt.), Error analysis: Perspectives on second language acquisition. London: Longman.

Fries, C. C. (1945). Teaching and learning of English as a foreign language. Ann Arbor: The University of Michigan Press.

Jian, M. P. (1974). Error analysis: Source, cause and significance. DIm. J. C. Richards (pnyt.), Error analysis: Perspectives on second language acquisition. London: Longman.

Dewan Bahasa dan Pustaka. (2007). Kamus Dewan edisi keempat. Kuala Lumpur, Malaysia: Dewan Bahasa dan Pustaka.

Matthews, P.H. (1991). Morphology. New York: Cambrige University.

Medan Sandra Kasih. (2003). Analisis kontrastif dan keanekabahasaan. Jurnal Bahasa, 47(10), 36-40.

Nik Safiah Karim, Farid M. Onn, Hashim Haji Musa \& Abdul Hamid Mahmood (pnyt). (2015). Tatabahasa Dewan edisi ketiga. Kuala Lumpur, Malaysia: Dewan Bahasa dan Pustaka.

Norehan Muhamad. (2009). Analisis kesilapan: Satu kajian terhadap karangan murid murid Orang Asli. Jurnal Penyelidikan DEDIKASI, 1, 119-136.

Pengajaran Bahasa Melayu dalam Kalangan Pelajar Asing: Analisis Pola Kesalahan Tatabahasa dalam Penulisan 
Rasid Mail \& Raman Noordin. (2015). Penyelidikan Peringkat Sarjana, Pendekatan Kualitatif sebagai Altenatif. Kota Kinabalu, Malaysia: Penerbit Universiti Malaysia Sabah.

Richards, J. C. (pnyt.) (1974). Error analysis: Perspectives on second language acquisition. London: Longman.

Sidek Mohd Noah. (2002). Reka bentuk penyelidikan falsafah, teori dan praktis. Selangor, Malaysia: Penerbit Universiti Putra Malaysia.

Ting, S. H., Mahadhir, M., \& Chang, S. L. (2010). Grammatical errors in spoken English of university students in oral communication course. GEMA Online Journal of Language Studies, 10(1), 53-70.

Yong, C. C., \& Subramaniam, V. (2012). Analisis kesilapan dalam pembelajaran Bahasa Melayu oleh pelajar asing. GEMA OnlineTM Journal of Language Studies, 12(2), 667-692. 


\section{Lampiran 1}

\section{Ortografi (kesalahan ejaan)}

\begin{tabular}{|c|c|c|c|}
\hline Negara & Kesilapan & Pembetulan & Kekerapan \\
\hline \multirow{45}{*}{ Bangladesh } & pebna & pernah & 1 \\
\hline & dilahinkan & dilahirkan & 1 \\
\hline & dilahirakan & dilahirkan & 1 \\
\hline & dilharikan & dilahirkan & 1 \\
\hline & belajen & belajar & 1 \\
\hline & plajar & pelajar & 1 \\
\hline & plajer & pelajar & 1 \\
\hline & plejar & pelajar & 1 \\
\hline & akhirhya & akhirnya & 1 \\
\hline & sepati & seperti & 1 \\
\hline & membil-belah & membeli-belah & 1 \\
\hline & beberadaan & keberadaan & 1 \\
\hline & peluag & peluang & 1 \\
\hline & keluaga & keluarga & 1 \\
\hline & kekuarga & keluarga & 1 \\
\hline & pertema & pertama & 2 \\
\hline & tanggu & tunggu & 1 \\
\hline & kepal terbang & kapal terbang & 1 \\
\hline & penenganbun & penerbangan & 1 \\
\hline & penerganbun & penerbangan & 1 \\
\hline & penyumbungan & penyambungan & 2 \\
\hline & penyanbungan & penyambungan & 1 \\
\hline & menghidukan & menghidupkan & 1 \\
\hline & tibu & tiba & 1 \\
\hline & juah & jauh & 1 \\
\hline & imigression & imigresen & 1 \\
\hline & imigresan & imigresen & 1 \\
\hline & $\begin{array}{l}\text { Lapangan Terbangan } \\
\text { Antarabangsa }\end{array}$ & Lapangan Terbang Antarabangsa & 1 \\
\hline & Lapanga Terbang Antarabangsa & Lapangan Terbang Antarabangsa & 2 \\
\hline & Lapungan Terga Antarbangsa Eport & Lapangan Terbang Antarabangsa & 1 \\
\hline & Lapagan Terbang & Lapangan Terbang & 1 \\
\hline & Lapangan tebung & Lapangan Terbang & 1 \\
\hline & perjalanal & perjalanan & 1 \\
\hline & barisal & berasal & 1 \\
\hline & berasar & berasal & 1 \\
\hline & menbesar & membesar & 1 \\
\hline & mengembil & mengambil & 1 \\
\hline & mengambi & mengambil & 1 \\
\hline & megambil & mengambil & 1 \\
\hline & adang & abang & 1 \\
\hline & lama keleman & lama-kelamaan & 1 \\
\hline & meneruska & meneruskan & 1 \\
\hline & pembeljana & pembelajaran & 1 \\
\hline & disikin & di sini & 1 \\
\hline & perjalan & perjalanan & 2 \\
\hline
\end{tabular}

Pengajaran Bahasa Melayu dalam Kalangan Pelajar Asing: Analisis Pola Kesalahan Tatabahasa dalam Penulisan 


\begin{tabular}{|c|c|c|}
\hline berjalanan & berjalan & 2 \\
\hline pangajaman & perjalanan & 2 \\
\hline parjalan & perjalanan & 1 \\
\hline perjalalan & perjalanan & 1 \\
\hline penjalanan & perjalanan & 1 \\
\hline ilah & ialah & 1 \\
\hline Selian itu & Selain itu & 1 \\
\hline Pada mulunya & Pada mulanya & 1 \\
\hline Salapas itu & Selepas itu & 1 \\
\hline bebrapa & beberapa & 1 \\
\hline simpanjang & sepanjang & 1 \\
\hline Malay & Melayu & 3 \\
\hline bergraduate & bergraduasi & 1 \\
\hline setiah & setiap & 1 \\
\hline tedapi & tetapi & 1 \\
\hline beresa & berasa & 1 \\
\hline setih & sedih & 1 \\
\hline gambira & gembira & 1 \\
\hline pertema & pertama & 1 \\
\hline Fakulti Economi dan Perniagan & Fakulti Ekonomi dan Perniagaan & 1 \\
\hline menganpha & mengapa & 1 \\
\hline berckongi & berkongsi & 1 \\
\hline mamulakan & memulakan & 1 \\
\hline mulakana & memulakan & 1 \\
\hline kecekam hariya & keesokan harinya & 1 \\
\hline ticket & tiket & 2 \\
\hline iket & tiket & 1 \\
\hline eport & airport & 2 \\
\hline mangaphbuang teksi & menghubungi teksi & 1 \\
\hline $\operatorname{dini}$ & kini & 1 \\
\hline university & universiti & 3 \\
\hline uniersiti & universiti & 1 \\
\hline University Sarawak Malays & Universiti Malaysia Sarawak & 1 \\
\hline bebrapa & beberapa & 1 \\
\hline simpanjang & sepanjang & 1 \\
\hline kali pertam & kali pertama & 1 \\
\hline kelinya & kalinya & 1 \\
\hline kempus & kampus & 1 \\
\hline pengania & pengajian & 1 \\
\hline kambali & kembali & 1 \\
\hline kembil & kembali & 1 \\
\hline nigara & negara & 1 \\
\hline pengelaman & pengalaman & 4 \\
\hline memindahakan & memindahkan & 1 \\
\hline 8th February & 8 Februari & 2 \\
\hline itu kota & ibu kota & 1 \\
\hline \begin{tabular}{|l|} 
menerma \\
\end{tabular} & menemani & 1 \\
\hline derjah celcius & darjah celcius & 1 \\
\hline kerenai & kerana & 1 \\
\hline berbegai & berbagai & 1 \\
\hline lake & tasik & 1 \\
\hline dakat & dekat & 1 \\
\hline selesa & selesai & 1 \\
\hline sampa & sampai & 1 \\
\hline
\end{tabular}

Pengajaran Bahasa Melayu dalam Kalangan Pelajar Asing: Analisis Pola Kesalahan Tatabahasa dalam Penulisan 


\begin{tabular}{|c|c|c|c|}
\hline & kasepian & kesepian & 1 \\
\hline & disni & di sini & 2 \\
\hline & barcadang & bercadang & 1 \\
\hline & mentarat & mendarat & 1 \\
\hline & pemeikaan & pemeriksaan & 1 \\
\hline & katam & kastam & 1 \\
\hline & begas & bagasi & 1 \\
\hline & turus & terus & 1 \\
\hline & dipadi & daripada & 1 \\
\hline & nigara & negara & 1 \\
\hline & tiletak & terletak & 1 \\
\hline & tinggit & tinggi & 1 \\
\hline & banguban & bangunan & 1 \\
\hline & concrit & konkrit & 1 \\
\hline & Restroren & Restoran & 1 \\
\hline & tangahari & tengah hari & 1 \\
\hline & pengaijian & pengajian & 2 \\
\hline & banya & banyak & 1 \\
\hline & tetap & tepat & 1 \\
\hline Jepun & saiens & sains & 1 \\
\hline & gumbira & gembira & 1 \\
\hline & gumbila & gembira & 1 \\
\hline & lateh & letih & 1 \\
\hline & mureka & mereka & 1 \\
\hline & bag & beg & 1 \\
\hline & begasi & bagasi & 1 \\
\hline & kominakasi & komunikasi & 1 \\
\hline & berjump & berjumpa & 1 \\
\hline & memjemput & menjemput & 1 \\
\hline & meninggkalkan & meninggalkan & 1 \\
\hline China & add & ada & 2 \\
\hline & social & sosial & 1 \\
\hline & fakulty & fakulti & 1 \\
\hline Brunei & perlepasan & pelepasan & 3 \\
\hline Indonesia & university & universiti & 3 \\
\hline Afrika & antarabagsan & antarabangsa & 2 \\
\hline Tajikistan & economi & ekonomi & 1 \\
\hline Morocco & plajare & pelajar & 1 \\
\hline Total & & & 161 \\
\hline
\end{tabular}

\section{Hukum D-M}

\begin{tabular}{|c|l|l|c|}
\hline Negara & \multicolumn{1}{|c|}{ Kesilapan } & \multicolumn{1}{c|}{ Pembetulan } & Kekerapan \\
\hline \multirow{2}{*}{ Bangladesh } & Malaysia Syarikat & Syarikat Malaysia & 1 \\
\cline { 2 - 4 } & Destinasi saya kedua & Destinasi kedua saya & 1 \\
\hline
\end{tabular}

Pengajaran Bahasa Melayu dalam Kalangan Pelajar Asing: Analisis Pola Kesalahan Tatabahasa dalam Penulisan 


\begin{tabular}{|l|l|l|c|}
\hline \multirow{4}{*}{} & pertama kali & kali pertama & 2 \\
\cline { 2 - 4 } & tunggu lain kapal terbang & Menunggu kapal terbang yang lain & 1 \\
\cline { 2 - 4 } & sewa rumah & rumah sewa & 1 \\
\hline Jepun & pertama kali & kali pertama & 1 \\
\cline { 2 - 4 } & Kawan-kawan baik hati saya & Kawan-kawan saya baik hati & 1 \\
\cline { 2 - 4 } & pertama negara asing & negara asing pertama & 1 \\
\cline { 2 - 4 } & hati baik & baik hati & 1 \\
\cline { 2 - 4 } & seronok kehidupan & kehidupan seronok & 1 \\
\cline { 2 - 4 } & saya fakulty & & 1 \\
\cline { 2 - 4 } & & Fakulti saya & 1 \\
\hline China & pertama kali & & 1 \\
\cline { 2 - 4 } & & kali pertama & 1 \\
\hline Indonesia & minggu hari pertama & hari pertama / minggu pertama & 1 \\
\cline { 2 - 4 } & & & 1 \\
\hline Afrika & bahasa Melayu peperiksaan & Peperiksaan bahasa Melayu & 1 \\
\hline Tajikistan & pertama kali & & 1 \\
\hline Morroco & & kali pertama & \\
\hline Total & & & 1 \\
\hline
\end{tabular}

\section{Unsur lewah}

\begin{tabular}{|c|c|c|c|}
\hline Negara & Kesilapan & Pembetulan & Kekerapan \\
\hline \multirow[t]{6}{*}{ Bangladesh } & $\begin{array}{l}\text { la adalah perjalanan pertema saya } \\
\text { menaiki kapal terbang, saya berasa } \\
\text { seronok perjalanan pertema saya. }\end{array}$ & $\begin{array}{l}\text { Ini adalah perjalanan pertama } \\
\text { saya menaiki kapal terbang dan } \\
\text { sangat menyeronokkan. }\end{array}$ & 1 \\
\hline & $\begin{array}{l}\text { la kapal terbang } \\
\text { tinggi dan semakin } \\
\text { tinggi. }\end{array}$ & $\begin{array}{l}\text { Kapal terbang mulai bergerak } \\
\text { tinggi ke } \\
\text { udara. }\end{array}$ & 1 \\
\hline & $\begin{array}{l}\text { Saya nampak bandar- bandar, } \\
\text { kampung- kampung, pokok- pokok dan } \\
\text { padang- padang, rumah- rumah dan } \\
\text { pokok- pokok kelihatan sangat kecil. }\end{array}$ & $\begin{array}{l}\text { Saya melihat pemandangan } \\
\text { bawah dari atas udara yang } \\
\text { kelihatan sangat kecil. }\end{array}$ & 1 \\
\hline & $\begin{array}{l}\text { Saya ingin berkongsi pengalaman } \\
\text { perjalanan bagaimana saya datang ke } \\
\text { Malaysia untuk pertama kali. }\end{array}$ & $\begin{array}{l}\text { Saya ingin berkongsi pengalaman } \\
\text { kali pertama saya datang ke } \\
\text { Malaysia. }\end{array}$ & 1 \\
\hline & $\begin{array}{l}\text { Keesokan harinya saya tiba di } \\
\text { Lapangan Terbang dan tempahan- } \\
\text { tempahan saya telah dilakukan } \\
\text { sebelum ini. }\end{array}$ & $\begin{array}{l}\text { Saya telah menempah tiket } \\
\text { penerbangan dan bergerak ke } \\
\text { Lapangan Terbang pada keesokan } \\
\text { harinya. }\end{array}$ & 1 \\
\hline & $\begin{array}{l}\text { Saya sangat sangat } \\
\text { suka Sarawak. }\end{array}$ & $\begin{array}{l}\text { Saya sangat suka } \\
\text { Sarawak. }\end{array}$ & 1 \\
\hline
\end{tabular}

Pengajaran Bahasa Melayu dalam Kalangan Pelajar Asing: Analisis Pola Kesalahan Tatabahasa dalam Penulisan 


\begin{tabular}{|c|c|c|c|}
\hline \multirow[t]{9}{*}{ Bangladesh } & $\begin{array}{l}\text { la merupakan } \\
\text { sesuatu yang sangat terindah } \\
\text { bagi saya. }\end{array}$ & $\begin{array}{l}\text { la merupakan } \\
\text { sesuatu yang sangat indah bagi } \\
\text { saya. }\end{array}$ & 1 \\
\hline & $\begin{array}{l}\text { Jadi saya mendapat beberapa } \\
\text { jam untuk melawat Lapangan } \\
\text { Terbang Kuala Lumpur dan } \\
\text { sepanjang malam saya berjalan } \\
\text { di }\end{array}$ & $\begin{array}{l}\text { Sepanjang } \text { malam } r \text { saya } \\
\text { menghabiskan masa berjalan- } \\
\text { jalan di Lapangan Terbang } \\
\text { Antarabangsa Kuala Lumpur dan } \\
\text { kali }\end{array}$ & 2 \\
\hline & $\begin{array}{l}\text { la merupakan pengelaman yang } \\
\text { sangat terindah dalam hidup } \\
\text { saya. }\end{array}$ & $\begin{array}{l}\text { la merupakan pengalaman yang } \\
\text { terindah dalam hidup saya. } \\
\text { la merupakan pengalaman yang } \\
\text { sangat indah dalam } \\
\text { hidup saya. }\end{array}$ & 2 \\
\hline & $\begin{array}{l}\text { Saya suka orang- orang dan } \\
\text { tempat- tempat disini. }\end{array}$ & $\begin{array}{l}\text { Saya suka orang Malaysia dan } \\
\text { tempat-tempat di sini. }\end{array}$ & 1 \\
\hline & $\begin{array}{l}\text { Kami pergi ke antarabangsa } \\
\text { lapangan terbang Kuching. }\end{array}$ & $\begin{array}{l}\text { Kami pergi ke Lapangan } \\
\text { Antarabangsa Kuching. }\end{array}$ & 1 \\
\hline & $\begin{array}{l}\text { Apabila itu saya mempunyai } \\
\text { bag begasi besar saya letih dan } \\
\text { lesu. }\end{array}$ & $\begin{array}{l}\text { Saya membawa } \\
\text { bagasi yang besah beg } \\
\text { membuatkan saya berasa letih. }\end{array}$ & 1 \\
\hline & $\begin{array}{l}\text { Saya gembira untuk berjumpa } \\
\text { mereka tetapi saya sedih } \\
\text { kerana } \\
\text { dengan nenek saya dan ibu } \\
\text { saya. }\end{array}$ & $\begin{array}{l}\text { Saya gembira berjumpa mereka } \\
\text { tetapi berasa sedih kerana } \\
\text { terpaksa berpisah dengan nenek } \\
\text { dan ibu saya. }\end{array}$ & 1 \\
\hline & Mereka berhati baik dan elok. & Mereka sangat baik hati. & 1 \\
\hline & $\begin{array}{l}\text { Tetapi kadang- kadang saya } \\
\text { rindu rumah saya, kawan saya } \\
\text { dan negara saya. }\end{array}$ & $\begin{array}{l}\text { Tetapi kadang kala saya rindu } \\
\text { akan rumah, kawan dan negara } \\
\text { saya. }\end{array}$ & \\
\hline China & - & - & - \\
\hline Brunei & $\begin{array}{l}\text { Saya amat sedih kerana harus } \\
\text { meninggalkan keluarga untuk } \\
\text { belajar. }\end{array}$ & $\begin{array}{l}\text { Saya sedih kerana terpaksa } \\
\text { meninggalkan keluarga untuk } \\
\text { belajar. }\end{array}$ & 1 \\
\hline
\end{tabular}

Pengajaran Bahasa Melayu dalam Kalangan Pelajar Asing: Analisis Pola Kesalahan Tatabahasa dalam Penulisan 


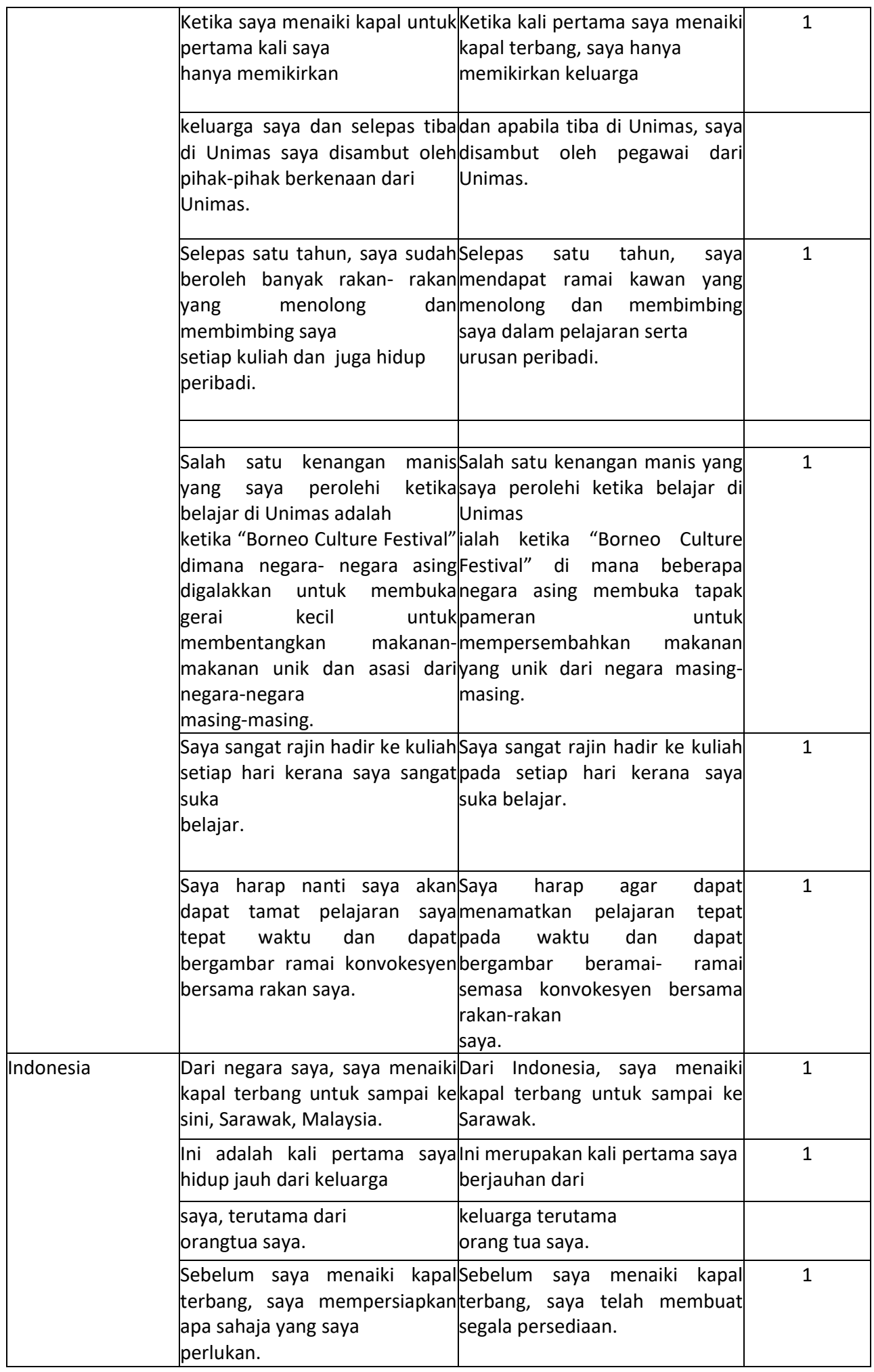

Pengajaran Bahasa Melayu dalam Kalangan Pelajar Asing: Analisis Pola Kesalahan Tatabahasa dalam Penulisan 


\begin{tabular}{|c|c|c|}
\hline & \multirow{2}{*}{\multicolumn{2}{|c|}{ 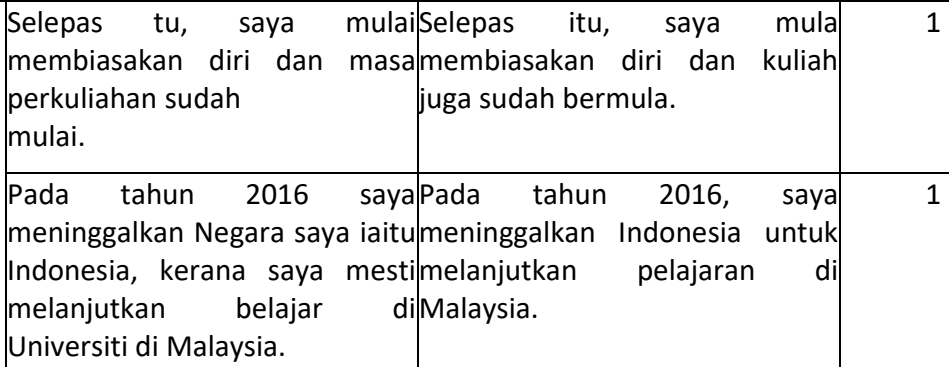 }} \\
\hline & & \\
\hline & $\begin{array}{l}\text { Saya sedih kerana terpaksa Saya sedih kerana terpaksa } \\
\text { berpisah dengan keluarga dan berpisah dengan keluarga dan } \\
\text { teman-teman saya yang ada di } \\
\text { kawan-kawan di Indonesia. } \\
\text { Indonesia. }\end{array}$ & 1 \\
\hline & \begin{tabular}{|l|l|} 
Setelah saya tiba di lapangan & Setelah tiba di Lapangan \\
terbang Malaysia iaitu KIA, saya & Terbang Antarabangsa Kuching, \\
langsung menukar wang saya saya terus menukar mata wang \\
dari Rupiah ke \\
Ringgit Malaysia. & Rupiah kepada \\
Ringgit Malaysia.
\end{tabular} & 1 \\
\hline & $\begin{array}{l}10 \text { minit kemudian teksi grab } 10 \text { minit kemudian, Grab tiba } \\
\text { tiba dan saya menaiki teksidan menuju ke rumah saya di } \\
\text { menuju rumah saya iaitu di Lorong Uni Garden 9D. } \\
\text { Lorong Uni } \\
\text { Garden 9D. }\end{array}$ & 1 \\
\hline \multirow[t]{3}{*}{ Afrika } & \begin{tabular}{l|l} 
Saya belajar di Fakulti \\
\end{tabular} & 1 \\
\hline & \begin{tabular}{|l} 
ekonomi dan perniagaan dan \\
$\begin{array}{l}\text { Ekonomi dan } \\
\text { saya mengambil ekonomi } \\
\text { antarabangsa. }\end{array}$ \\
mengambil kursus ekonomi \\
antarabangsa.
\end{tabular} & \\
\hline & \begin{tabular}{|lll} 
Saya ada kawan- kawan lelaki Saya mempunyai kawan-kawan \\
dan perempuan, kawan dalam kalangan pelajar \\
tempatan dan juga & tempatan serta & \\
antarabangsa. & antarabangsa. & \\
\end{tabular} & 1 \\
\hline Tajikistan & - & - \\
\hline Morroco & - & - \\
\hline Total & & 32 \\
\hline
\end{tabular}

\section{Leksikal (pengaruh bahasa ibunda/asing)}

\begin{tabular}{|l|l|l|c|}
\hline Negara & Kesilapan & Pembetulan & Kekerapan \\
\hline Indonesia & $\begin{array}{l}\text { Saya memiliki harapan selepas } \\
\text { selesai masa perkuliahan, saya } \\
\text { bekerja di syarikat besar dan } \\
\text { menolong orang lain yang } \\
\text { membutuhkan. }\end{array}$ & $\begin{array}{l}\text { Saya berharap selepas tamat } \\
\text { belajar untuk bekerja di } \\
\text { syarikat besar dan menolong } \\
\text { mereka yang memerlukan. }\end{array}$ & 1 \\
\cline { 2 - 3 } & $\begin{array}{l}\text { Selepas menukar wang saya } \\
\text { langsung mencari Grab untuk } \\
\text { pulang ke rumah saya. }\end{array}$ & $\begin{array}{l}\text { Selepas selesai menukar mata } \\
\text { wang saya terus mencari } \\
\text { Grab untuk pulang ke rumah. }\end{array}$ & 1 \\
\hline
\end{tabular}

Pengajaran Bahasa Melayu dalam Kalangan Pelajar Asing: Analisis Pola Kesalahan Tatabahasa dalam Penulisan 


\begin{tabular}{|l|l|l|c|}
\hline Jepun & $\begin{array}{l}\text { Fakulti saya di Sosial Saiens, dan } \\
\text { kursus studies antarabangsa. }\end{array}$ & $\begin{array}{l}\text { Fakulti saya di Sains Sosial dan } \\
\text { mengambil kursus bahasa } \\
\text { Melayu untuk pelajar } \\
\text { antarabangsa. }\end{array}$ & 1 \\
\hline Total & & 3 \\
\hline
\end{tabular}

Pengajaran Bahasa Melayu dalam Kalangan Pelajar Asing: Analisis Pola Kesalahan Tatabahasa dalam Penulisan 